Report of Investigations 2002-3

\title{
PALEONTOLOGICAL INVENTORY OF THE AMPHITHEATER MOUNTAINS, MT. HAYES A-4 AND A-5 QUADRANGLES, SOUTHCENTRAL ALASKA
}

by

Roben B. Blodgen

2002

This DGGS Report of Investigations is a final report of scientific research. It has received technical review and may be cited as an agency publication. 


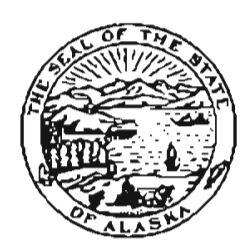

\author{
STATE OF ALASKA \\ Tony Knowles, Governor
}

\title{
DEPARTMENT OF NATURA L RESOURCES John T. Shively, Commissioner
}

\section{DIVISION OF GEOLOGICAL \& GEOPHYSICAL SURVEYS Milton A. Wiltse, Director and State Geologist}

Division of Geological \& Geophysical Surveys publications can be inspected at the following locations. Address mail orders to the Fairbanks office.
Alaska Division of Geological
University of Alaska Anchorage
Library
\& Geophysical Surveys
321 I Providence Drive
794 Universiry Avenue, Suite 200
Anchorage, Alaska 99508

Fairbanks, Alaska 99709-3645

Elmer E. Rasmuson Library

University of Alaska Fairbanks

Alaska Resource Library

3150 C Sireet, Suite 100

Fajrbanks, Alaska 99775-1005

Anchorage, Alaska 99503

\begin{abstract}
Alaska State Library
State Office Building, 8th Floor

333 Willoughby Avenue

Juneau, Alaska 9981 j-0571
\end{abstract}

This publication released by the Division of Geological \& Geophysical Surveys was produced and printed in Fairbanks, Alaska at a cost of $\$ 2$ per copy. Publication is required by Alaska Statute 4l, "to determine the potential of Alaskan land for production of metals, minerals, fuels, and geothermal resources; the location and supplies of groundwater and construction materials; the potential geologic hazards to buildings, roads, bridges, and other installations and structures; and shall conduct such other surveys and investigations as will advance knowledge of the geology of Alaska." 


\section{CONTENTS}

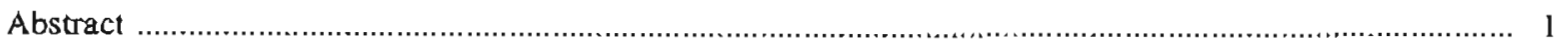

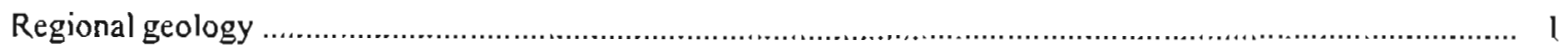

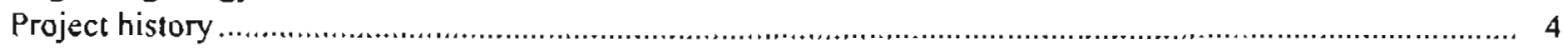

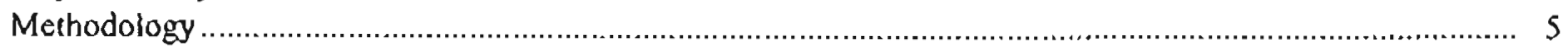

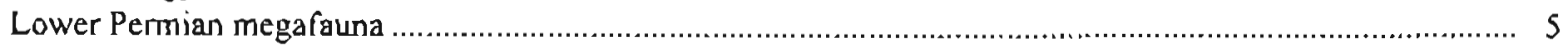

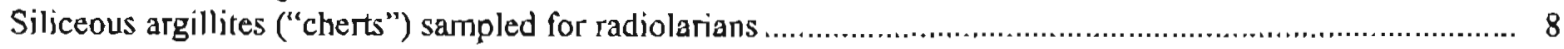

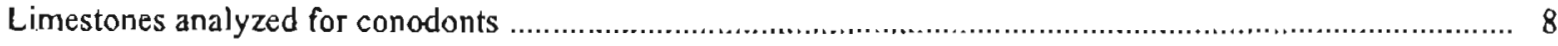

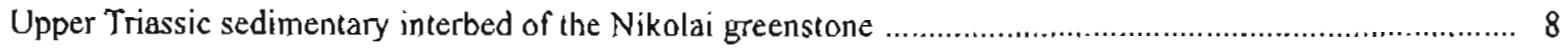

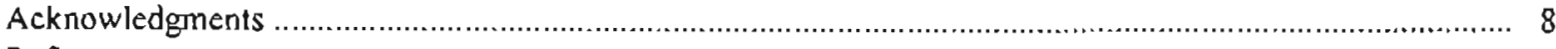

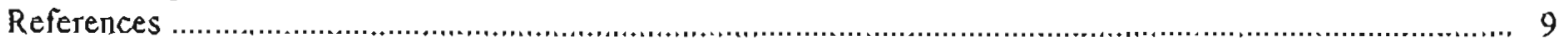

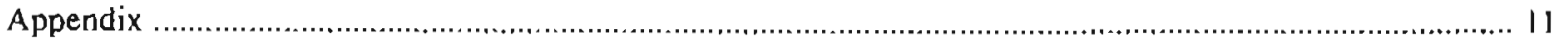

\section{FIGURES}

Figure 1. Index map showing location of the study area ............................................................

2. Columnar section of the Lower Permian to Middle Triassic stratigraphic succession ................... 3

3. Photos of megafossils recovered from ML Hayes A-5 Quadrangle ......................................... 7 


\title{
PALEONTOLOGICAL INVENTORY OF THE AMPHITHEATER MOUNTAINS, MT. HAYES A-4 AND A-5 QUADRANGLES, SOUTHCENTRAL ALASKA \\ by

\author{
Robert B. Blodgett'
}

\begin{abstract}
Paleontological sampling and study of pre-Nikolai Greenstone sedinentary rocks was conducted in the area of the Amphitheater Mountains, Mt. Hayes A-4 and A-5 quadrangles, southcentral Alaska. These rocks belong to the Tangle subterrane of the Wrangellia terrane and are best exposed in the "Wildhorse Canyon" section (about 213-244 m [700-800 $\mathrm{ft}$ thick) in the ML Hayes A-S Quadrangle. Two subunits are recognized in this section, both of which appear to have been deposited in a euxinic ("starved basin") paleoenvironment, as metazoans are notably absent. The only exception is the presence of poorly preserved megafossits of Early Permian age in calcareous sandstone turbidites $2.2 \mathrm{~km}(3.5 \mathrm{mi})$ northwest of the Wildhorse Canyon section. The megafossils occur in strata lithologically equivalent to the lower subunit. The upper subunit directly underlies the Nikolai Greenstone and consists of an approximasely $46-61 \mathrm{~m}(150-200 \mathrm{ft})$ thick succession of thin-bedded gray argillite, black carborraceous shale and siltstone, and very minor calcareous mudstone and limestone concretions. Although the upper subunit lacks fossils, its lithology suggests correlation in pan with the unnamed Triassic shale, lime, and chert unit recognized in the adjacent Slana River subterrane in the soucheastem

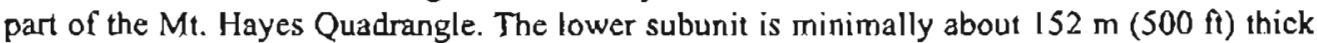
and consists primarily of medium- to thick-bedded, green siliceous argillite. The subunit is in part of Early Permian age, based on the above-mentioned megafossil collection. The decrease in siliceous sediment and concomitant increase of a black carbonaceous and calcareous component in the upper subunit (compared to that of the lower subunit) suggest that slight uplift occurred in the basin before initial outpouring of the basal pillowed submarine basalts of the Nikolai Greenstone. A presumably older, isolated, thick limestone body was examined in the ML. Hayes A 4 Quadrangle, but yielded neither megafossils nor microfossils.
\end{abstract}

\section{REGIONAL GEOLOGY}

This study focused on unraveling the stratigraphy and paleontology of sedimentary rocks found subjacent to the Nikolai Greenstone in the Amphitheater Mountains of the Mt. Hayes A-4 and A-5 quadrangles. southcentral Alaska (fig. 1). Some attention was also given to the minor sedimentary interbeds found in the lowermost pillow basalt subunit that forms the base of the Nikolai Greenstone in this area. The rocks of this region are considered to be part of the well-known Wrangellia terrane, an accreted terrane that in Late Triassic time lay near the paleoequator (Hillhouse, 1977; Blodgett and Frýda, 2001; Blodgett el al., 2001) and includes a distinctive succession of Late Paleozoic to Jurassic volcanics and sediments that can be traced from the Hells Canyon region of the Oregor-Idaho border, through Vancouver Island of westem British Columbia. and into the Wrangell Mountains and northern Talkeetna Mountains of interior and southcentral Alaska. The rocks studied for this project belong to the Tangle subterrane of Wrangellia (Nokleberg el al, 1981, 1982, 1992). This subterane is recognized south of the Eureka fault The studied rocks crop out on both the north and south flanks of the Amphitheater Mountains. The adjoining Slana River subterrane lies north of the Tangle subterrane, and is bounded by the Denali fault and Broxson Gulch thrust to the north, and by the Eureka fault to the south. The Tangle subterrane was differentiated from the Slana River subterrane in having a "thinner sequence of Upper Paleozoic and Lower Triassic sedimentary and tuffaceous rocks, and a thicker sequence of unconformably overlying pillow basalt and subaerial basall flows of the Triassic Nikolai Greenstone" (Nokleberg et al., 1992, p. 10).

Sediments underlying the Nikolai Greenstone in the Mt. Hayes A-4 and A-5 quadrangles have not been previously studied in detail, and are noted only with cursory

'Deparmeats of Zoology and Geosciences, Oregon State University, Corvallis, Oregon 97331. 


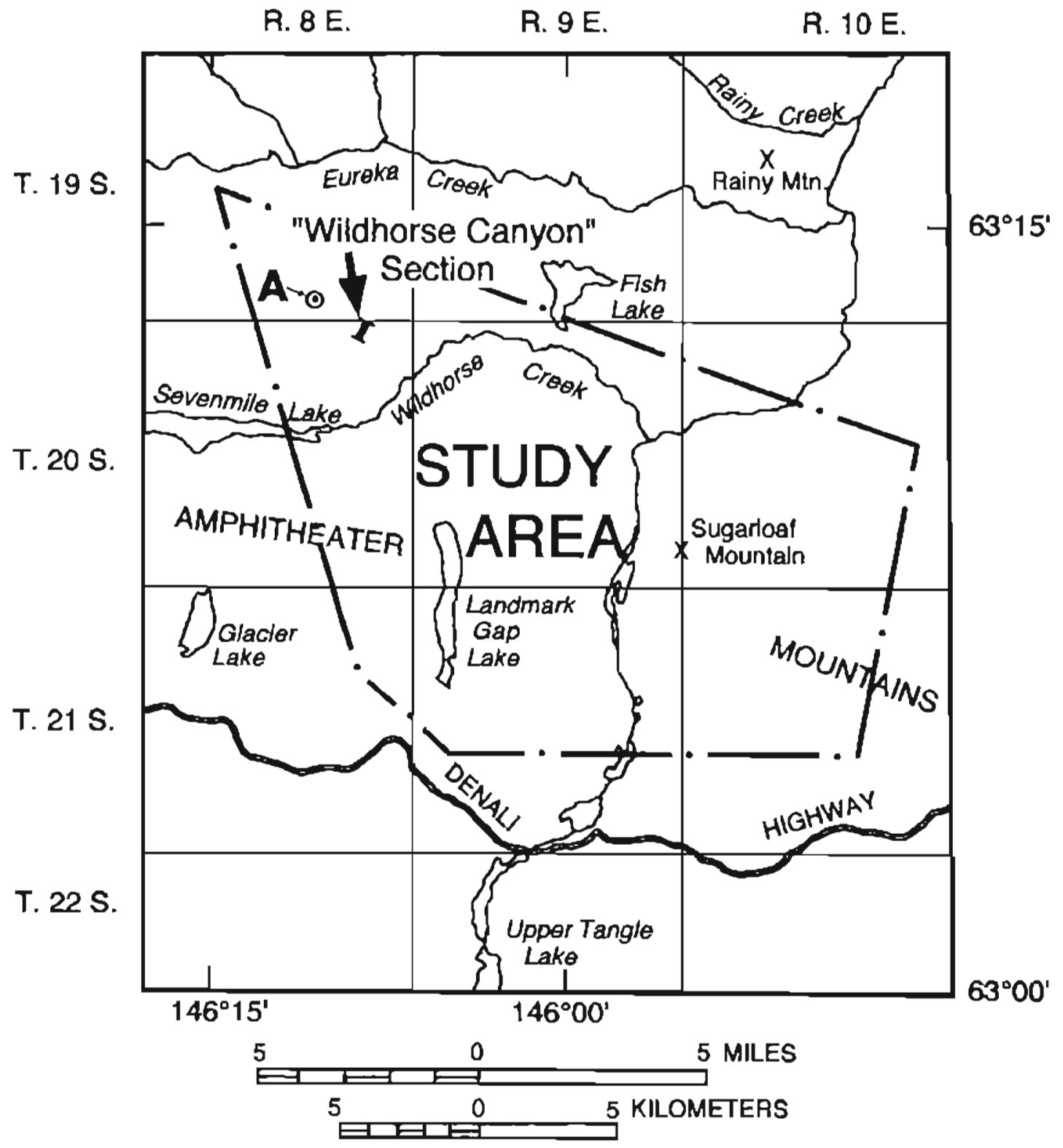

Figure I. Index map showing location of the study area (within dot-dash line), the Wildhorse Canyon section. and the Lower Permian fossil locality OIRBS8 (locality A on map) in the southcentral portion of the Mt. Hayes 1:250,000-scale quadrangle.

explanation on the geologic maps of Stout (1976) and Nokleberg et al. (1992). Nokleberg et al. (1992) denoted these sediments as their Pzt unit (aquagene ruff, argillite, limestone, chert, andesite tuff, and greenstone) of Late Paleozoic age. This unit appears to be a catch-all unit, which does not directly correspond with most of the pre-Nikolai Greenstone sediments examined in this study. Their unit description appears to have been based upon examination of what is either a highly altered, stoped block or roof pendant of metasedimentary rocks surrounded by gabbroic sills and exposed in the SW1/4 of section 3 and NW1/4 of section 10, T2 IS, R IOE, Mt. Hayes A-4 Quadrangle. The only age inference for this unit was provided by a single collection (fossil locality 125 of Nokleberg et al., 1992), which was identified by N.J. Silberling as being indeterminate bryozoans and thought to indicate a Late Paleozoic age. The author spent a full day investigating this exposure and surrounding ares, and the limestone locality with the reported bryozoans was revisited. Numerous amorphous siliceous stringers are present, but none of these appear to tuly represent the remains of bryozoans. Hence, the reputed 
Late Paleozoic age for this locality remains unproven. Efforts were made to relocate the specific original collection in the USGS fossil repository in Denver. Colorado, where the collections of Silberling are deposited However, this sample was apparently discarded, as it was not present among the collections from the central Alaska Range.

This limestone locality and adjoining exposures of metachert stand out from the vast majority of exposed pre-Nikolai sediments, which are discussed below. It seems probable that part of the poor framework given for the pre-Nikolai sediments in the Nokleberg et al. (1992) repor may be due to the very limited field time (less than one day) spent by the USGS geologists who were involved in reconnaissance mapping of this general area (Norm Silberling, oral communication, 2001). Good exposures of the pre-Nikolai sedimentary package are so few and scattered that considerably more time was needed to properly inventory them. Stout (1976) recognized a unit he designated as his TRtl unit of his Tangle Lakes Formation. He described the TRtl unit as one composed of "siliceous, light-green to gray tuffs and agglomerate interlayered with tuffaceous sediments and black shale" (Stout, 1976, map legend on Plate 1). This unit corresponds in part to the Pzt unit of Nokleberg et al. (1992), though the portions ascribed to being agglomerate are considered here to probably belong to the underlying Tetelna Volcanics of Pennsylvanian age. Mapping in progress by geologists associated with M.A.N. Resources indicates that much of Stout's stratigraphy is incorrect, and that such units as his TRpm unit (Paxson Mouncain basalt) are in part equivalent to basaltic portions of his Tangle Lakes Formation (equivalent to Nikolai Greenstone herein).

Figure 2. Columnar section of the Lower Permian to Middle Triassic stratigraphic succession exposed in the "Wildhorse Conyon" section, siruated in the NE\% of section 2, T2OS, R8E, Mt. Hayes A-5 Quadrangle. The uppermost unit shown here is a gabbroic sill that closely underlies exposures of the Nikolai Greenstone upsection. The secrion is schematic only, due to inaccessibility to the middle portion of the section (i.e. the comtact between the upper and lower subunits is approximately localed). The primory lithologic difference between the upper and lower subunits is the thinner bedding and greater abundance of black carbonaceous shale and minor carbonate in the upper subunit, in contrast to the thicker bedding and nore siliceous character of the argillaceous rocks in the lower subunit. Relative positions of sample localities for conodon's (01RB54, 55) and radiolarians (OIRBS7, 59A, and 65) indicated.
The primary pre-Nikolai Greenstone sedimentary unit exposed in the Amphitheater Mountains (Tangle subterrane of the Wrangellia terrane) is a succession of thin- to medium-bedded siliceous angillites (some field geologists would actually call (hem cherts), carbonaceous black shales and mudstones, and, rarely, calcareous mudstone. This unit is sporadically exposed at a number of localities on both the north and south sides of the Amphitheater Mountains, the latter consisting essentially of an east-west-trending synclinorium cored by the Nikolai Greenstone in the study area. The minimum thickness for the entire pre-Nikolai sedimentary succession is $213-244 \mathrm{~m}$ (700-800 $\mathrm{ft}$ ), although this thickness may be somewhat exaggerated due to the abundant presence of layered incusive sill-like bodies that are probably co-magmanic with the overlying Nikolai Greenstone.

Two separate subunits are distinguished at the best exposed section (fig. 2) of this unit in the canyon of a north-flowing stream in the NE'/1 of section 2, T20S, R8E, Mt. Hayes A-5 Quadrangle. This section is denoted herein as the Wildhorse Canyon section (see locality A in fig. 1 for location), the name being derived

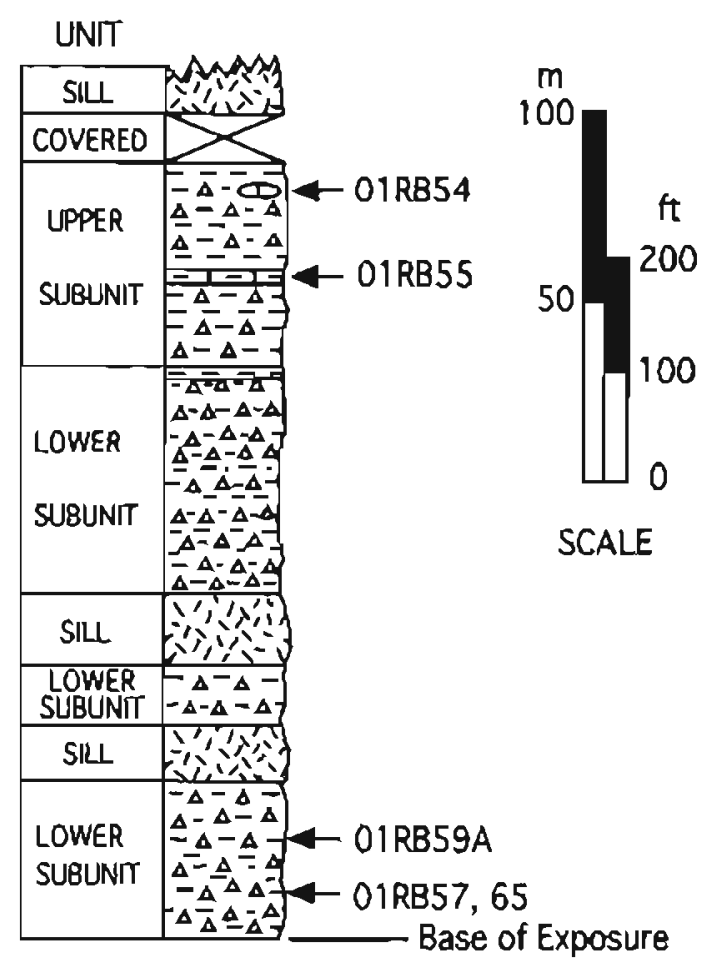

\section{EXPLANATION}

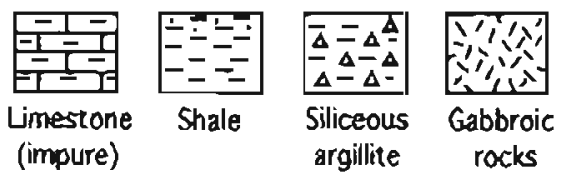


from Wildhorse Creek, the closest named geographic fearure to this canyon, located approximately $2 \mathrm{~km}$ to the southeast. The upper subunit is roughly $46-61 \mathrm{~m}$ (150-200 ft) thick and closely adjoins the nearby overlying Nikolai Greenstone, but the upper contact of the upper subunit here is with a gabbroic sill that has been intmuded between it and the Nikolai. This subunit directly underlies the Nikolai Greenstone with a non-conformable contact that is recognized in a small exposure situated in the $S W 1 / 4$ of section 3, T2IS, R9E, Mt. Hayes A-5 Quadrangle. About $3 \mathrm{~m}$ (10 fi) of the uppermost sediments can be observed in direct contact with overlying pillow basalts of the Nikolai at this exposure. The upper subunit differs from the lower subunit in being markedly thinner bedded in character, and in possessing significant interbedded black carbonaceous shale or mudstone intervals, as well as several minor intervals of calcareous mudstone (approaching limestone) and limestone concretions. The exact nature of the contact between the upper and lower subunits could not be determined in the Wildhorse Canyon section due to its location in an inaccessible portion of the creek (steep walls and ice cover at the time of the field study). However, examination of beds above and below the zone containing the contact interval indicates that the contact is most likely gradational.

An intensive search for megafossils in the upper subunit during the two-week-long field season proved fruitless. Subsequent laboratory analysis for conodonts and/or radiolarians from two carbonate-rich samples (localities 0IRB54 and 55) was also negative. The depositional environment of this subunit appears to be that of a "starved," euxinic (anoxic) basin, based on the total absence of fossils. However, the presence of an enhanced black carbonaceous and calcareous component suggests a somewhat shallower environment than that of the underlying lower subunit, perhaps related to uplift of the basin before initial outpouring of the basal pillowed submarine basalts of the Nikolai Greenstone. In the absence of fossil evidence, the upper subunit would appear to be bracketed in age stratigraphically as being older than the superjacent Nikolai Greenstone (of Middle Triassic to Late Triassic age) and younger than the subjacent lower suburnit which yielded an Early Permian megafauna. On the basis of its lithology, the upper subunit may be in pant a deeper-water equivalent of the unnamed shate, lime, and chert unit of Richcer et al. (1977) and Nokleberg er al. (1992, p. 9) in Slana River subterrane exposures in the southeastem part of the Mt. Hayes Quadrangle (both units contain abundant black carbonaceous shale). The Slana River subterrane unit directly underlies the Nikolai Greenstone and contains abundant specimens of the flat-clam Daonella, indicative of a Middle Triassic age. Similar associacions of Daonella-bearing sediments directly beneath the Nikolai are also known further southeast from the Wrangell
Mountains (type area of the Wrangell terrane), as wel] as beneath the Karmutsen Volcanics, the Nikolai Greenstone equivalent on Vancouver Island.

The lower subunit is consistencly thicker bedded than the upper subunit, and its dominant siliceous argillites tend to be greener in color, rather than the medium gray color associated with the siliceous argillites of the latter. The lower subunit appears to have a minimum thickness of about $152 \mathrm{~m}(500 \mathrm{ft})$. Like the overlying upper subunit the depositional environment of the lower subunit also appears to have been that of a euxinic (anoxic) basin that probably formed atop the submerged island arc edifice represented by the older Tetelna Volcanics. The anoxic environmental interpretation is strongly suppored by the lack of biogenic sedimentary structures (trace fossils) and the even, parallel laminations (indicating no biocurbation) that can be observed in the siliceous argillites. Like the fruitless search in the upper subunit, no megafossils were observed in the lower subunit in the Wildhorse Canyon section, and analyses for radiolarians from three siliceous argillite ("chert") samples from the lower subunit (localities 0IRB57, 01RB59A, and 01RB65) were also negative. Fortunately, age control for the lower subunit is provided by a limited fauna of megafossils recovered from a site (locality 01 RB58) on trend $2.2 \mathrm{~km}$ to the northwest of the Wildhorse Canyon section. The locality was part of a thin rurbidite sandsione interval within argillaceous rocks otherwise similar to thase of the lower subunit. The limited megafauna consisted of brachiopods, crinoids, and bryozoans (see discussion below) that indicate an Early Permian age. In terms of its age, the lower subunit is equivalent to the Lower Permian Eagle Creek Formation of the Mankomen Group (Richter and Dutro, 1975; Richter el al., 1977) of the Slana River subterrane to the northeast However, the lower suburit obviously differs both lithologically and faunally from the much shallower environments represented by deposits of the Eagle Creek Formation.

\section{PROJECT HISTORY}

This work was contracted by the Alaska Division of Geological \& Geophysical Surveys as pan of a collaborative research project with the Geological Survey of Canada to compare the geological setting of the Wrangellian ultramafic rocks of southcentral A laska with those in westem Canada. Initial paleontologic work for this study was started in April 2001. It included an exrensive literarure search for papers pertaining to geological mapping, as well as to paleontological and strarigraphic studies conducted in the ML Hayes Quadrangle. The author also made an inventory of his extensive archives of old intemal USGS fossil reports for the Mt. Hayes 1:250,000-scale quadrangle. Unfortunately, only two collections previously were submitted 
from the field area for study by USGS paleontologists (both reports were available to the present investigator). The fieldwork phase of the study was conducted July 6-16, 2001, based out of the M.A.N. Resources camp in the Broxson Gulch area. Logistical support to and from the field area was by helicopter (using both a Hughes 500 and a smaller Robinson R-22 helicopter) The laboratory phase of the study began in October 2001 and continued through December 2001. This phase included the acidizarion of the megafossil-bearing samples from locality 01 RB58, as well as acidization of the conodont and radiolarian samples in dilute acetic (or formic) and hydrofluoric acids, respectively. The megafossils from this locality (01RB58) were photographed in December $200 \mathrm{l}$.

\section{METHODOLOGY}

All sedimentary rock outcrops visited were examined in detail for megafossils. This included the physical breaking up of numerous platy shales and getting close and physical on hands and knees with scores of rubble crops. Unfortunately, the anoxic environments represented by the vast bulk of examined exposures (represented by localities OIRB40, 42, 43, 44, 45, 46, $47,48,54,55,56,57,59,59 \mathrm{~A}$, and 65 ; see Appendix for their locations) were barren of fossils, with the exception of the calcareous sandstone turbidites noted at locality 01 RB 58 in the Mt. Hayes A-5 Quadrangle.

The deep, anoxic environment represented by the pre-Nikolai sediments explains the previous lack of recovered fassil remains from the field area. Until this investigation, only one pre-Nikolai Greenstone megafossil locality was noted in the shudy area in probable Late Paleozoic limestones (locality 125 of Nokleberg et al., 1992); however, visitation and sampling of the outcrop by the author has convinced him that the previously identified bryozoans were most likely misidentified inorganic dendritic siliceous blebs, which could easily be mistaken for bryozoans by untrained eyes. Efforts were made in October $200 \mathrm{I}$ to relocate this sample in the Triassic (and extraneous) collections of the USGS in Denver (assembled for the most par by Norm Silberling), but the sample in question could not be located in the several drawers of Triassic materials from the central Alaska Range. The same holds true for the Upper Triassic sedimentary interbeds in the Nikolai Greenstone that reputedly yielded the flat clam Daonella or Halobia (fossil locality 124 of Nokleberg el al., 1992). Numerous shaly and/or platy siltstone lithologic samples were also examined subsequently in the laboratory under a binocular microscope, but again no visible megafossils were noted.

Sampling for two microfossil groups (conodonts and radiolarians) was also conducted in the laboratory.
Several exceedingly large limestone samples $(>7 \mathrm{~kg})$ were dissolved in either dilute acetic or formic acid. After dissolution, the samples were decanted through a 230-mesh screen sieve and examined under a binocular microscope for both conodonts and radiolarians. In all cases no organic remains were recovered. Three "chert" (actually highly siliceous argillite) samples were dissolved in dilute hydrofluoric acid. Unfortunately, examination of the residues gave only negative résults.

\section{LOWER PERMIAN MEGAFAUNA}

Only a single megafossil-bearing site was discovered in the two-week field study of pre-Nikolai Greenstone sediments of the Amphitheater Mountains area. This field station (01RB58) is situated along the north side of the unnamed creek (just east of the big bend: UTM coordinates: 541080,7010965$)$ approximately $2.2 \mathrm{~km}$ ( $1.4 \mathrm{mi}$ ) to the northwest of the Wildhorse Canyon section, Mt. Hayes A-5 Quadrangle. The site consisted of two separate, dark gray, recessive, calcareous, turbiditic sandstone intervals, up to $10 \mathrm{~cm}$ thick, that are situated in a succession of thick-bedded graygreen argillites lithologically identical to the rocks typical of the lower subunit of the Wildhorse Canyon section. These pinch and swell in thickness laterally, and crinoid ossicles were readily noted with a hand lens. The locality is almost identical to the so-called "Daonella" locality that Bill Ellis informed me about from previous field work in the area; however, these "fossils" which were intensively collected the previous year and sent to Norman Silberling (Denver, CO, retired USGS paleontologist with expertise in Triassic fossils), were idencified as being inorganic in origin. The large sample of turbidite sandstone collected from this lacality was broken apar by a hydraulic rock splitter into small pieces 3-4 $\mathrm{cm}$ in maximum dimension, and then submerged in weak acetic acid to etch the matrix to better expose potential megafossils as casts and molds, as well as trying to recover conodonts. Aralysis of the fine residue (saved on 230-mesh sieve) for conodionts was negative, but fortunately a significant recovery was made of comminuted shelly fossils (notably brachiopods, bryozoans, and crinoid ossicles) that provide the only age control for these pre-Nikolai Greenstone sedimentary rocks. The illustrated fossil specimens, as well as all ancillary fossil material recovered from this locality, are deposited in the University of Alaska Museum (abbreviation UAM) at Fairbanks, Alaska. The following faunal elements were identified at this locality:

Brachiopoda:

Chonetinella sp. (figs. 3.1-3.2)

echinoconchid brachiopod, genus and species indeterminate (figs. 3.3-3.4) 
Spiriferellina sp. (fig. 3.6)

indeterminate smooth brachiopod (fig. 3.5)

indeterminate ribbed brachiopod (fig. 3.7)

Bryozoa:

Stick-like, generically indeterminate cryptostome bryozoan fragments (fig. 3.8).

\section{Echinodermata:}

Numerous crinoid ossicles (stem fragments) of varying sizes and morphotypes (fig. 3.9)

Age: Neither the poorly preserved cryptostome bryo zoans nor crinoid ossicles have any age implications other than being typical components of other Permian faunal assemblages seen in accreted terranes of southem Alaska (cryptostome bryozoans do not range higher than the Permian, and bryozoans are almost wholly absent in Alaskan Triassic rocks). The brachiopods from this sample have considerably greater importance in age determination of this horizon. The genus Chonetinella is represented by a single poorly preserved external mold of a ventral valve (figs. 3.1-3.2) that nonetheless shows the general shape of the shell as well as its faint, weakly capillate micro-ornamentation. Chonelinella Ramsbottom, 1952, according to the newly revised Brachiopod Treatise (Racheboeuf, 2000), is a relatively widespread cosmopolican genus known from Upper Carboniferous-Lower Permian (Kungarian) strata of Europe, North America, and South America. However, it is also relatively abundant at a number of sites in the Russian Arctic (i.e., Kasimovian strata of the northeast Russian Platform, see Kalashnikov, 1980, Pl. 2, figs. 9 10 ), and it is apparently common in other Wrangellia terrane localities such as the Late Pennsylvanian age Mount Mark Formation on Vancouver Island, British Columbia (see Ludvigsen and Beard, 1997, fig. 17).

One single intemal mold of the posterior portion of a productoid brachiopod ventral valve was also recovered (figs. 3.3-3.4). This shell fragment has the typical fearures of the Lower Carboniferous-Permian family Echinoconchidae, and at present is simply identified as an echinoconchid brachiopod, genus and species indeterminate. Lack of an exterior and more detailed knowledge of the cardinal process precludes unambiguous genus-level identification. However, the form of the cardinal process most closely approaches that of the genus Waggenoconcha Chao, 1927 (compare with illustrations given in Muir-Wood and Cooper, 1960, Pl. 90 , figs. 3,8 ) and this southcentral Alaska specimen may well belong to the genus Wangenoconcha, but again, lack of a preserved exterior does not allow further generic detemination.

The genus Spiriferellina Frederiks, 1924 (imprint 1919) is represented by several fragmentary extemal molds (fig. 3.6). These specimens show the typical closely spaced, imbricate growth lamellae that are characteristic for the genus. According to Pitrat (1965), this genus is known from both Lower and Upper Permian strata of Europe, Asia, and North America. The genus is a typical element of the so-called cool-water "Arctic Permian" fauna (see Dutro [1961] and Dutro and Saldukas [1973] for review of Arcric Permian faunas). Arctic Permian faunas are recognized in Germany (in the classic Zechstein), England, Greenland (Dunbar, 1955), Russian Platform, Novaya Zemlya, Siberia, and are especially common in Late Permiar strata of the Chulitna terrane exposed in the Healy A-6 Quadrangle, southcentral Alaska (Blodgett and Clautice, 1998a,b, 2000). The occurrence in the Chulitna terrane is characterized by the type species of Spiriferellina. S. cristata (Schlotheim). Unfortunately the very fragmentary nature of the material illustrated from the Amphitheater Mountains area precludes species-level taxonomic assignment Extra-cool (presumably warm-water Tethyan) occurrences of the genus, however, are also known in India, Timor, southern Yunnan, and the Shan States of Southeast Asia. In addition, two other brachiopod species are present at the Amphitheater Mountains locality and each is represented by a single parial internal mold. These molds are of an indeteminate smooth brachiopod (fig. 3.5) and an indeterminate ribbed brachiopod (fig. 3.7).

The overlap of the ranges for the brachiopod genera reported here indicates an Early Permian age for this locality. Ecologically it is difficult to reconstruct the original depositional environment of the source beds for the rurbidite deposit, but presumably it was from a shatlower source, perhaps from Early Permian shallow-shelf sediments, represented by Slana River subterrane rocks exposed to the northeast. The Lower Permian Eagle Creek Formation of the Markomen Group (Richter and Dutro, 1975; Richter et al., 1977) represents the age equivalent horizon in the Slana River subterrane. However, the lack of observed paleocurrent indicators at this locatity do not provide evidence that could indicate source direction.

Paleobiogeographically, this faunal assemblage contains typical elements of the so-called "Arctic Permian" fauna (see Dutro, 1961, and Dutro and Saldukas, 1973, for further discussion) that presumably characterized high-latioutude, cool Boreal paleolatitudes of the Permian. The presence of both Chonetinella and Spiriferellina are concordant with such an interpretation. It is interesting to note the often-mentioned Boreal or "Arctic Permian" aspect of Permian brachiopod faunas of southem Alaska's accreted terranes (notably the Farewell, Chulitna, Wrangellia, and Alexander terranes). Their seemingly cool-water, moderate- to high-latitude setting stands in strong contrast with the markedly tropical 


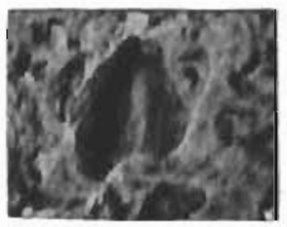

1

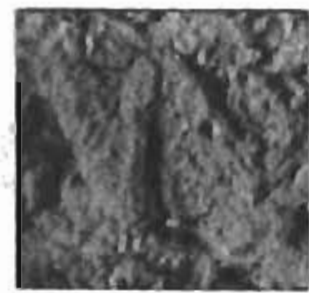

2

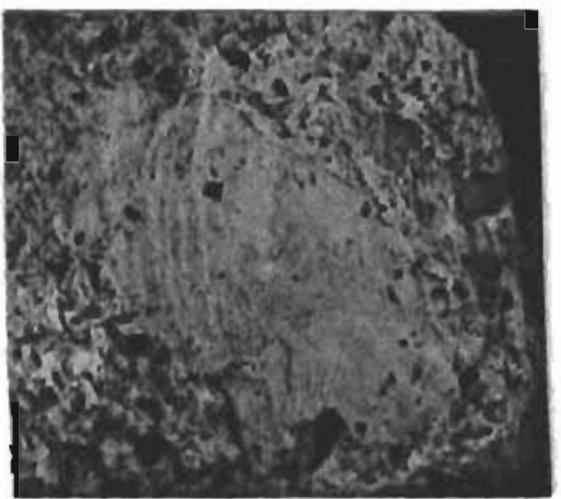

5

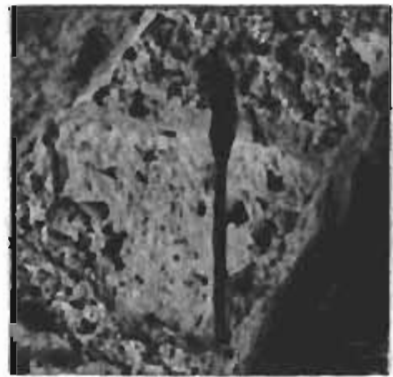

3

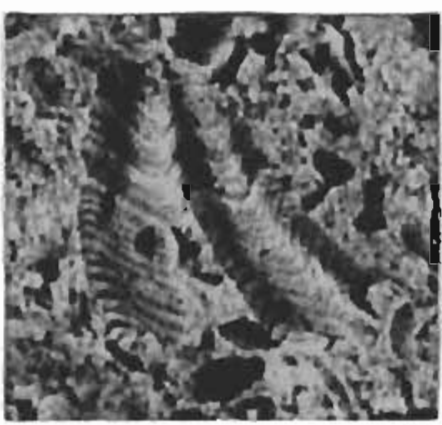

6

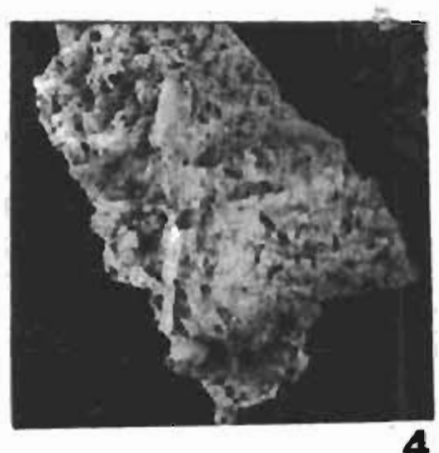

4

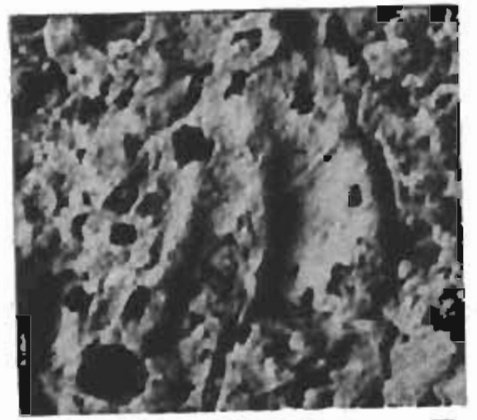

7
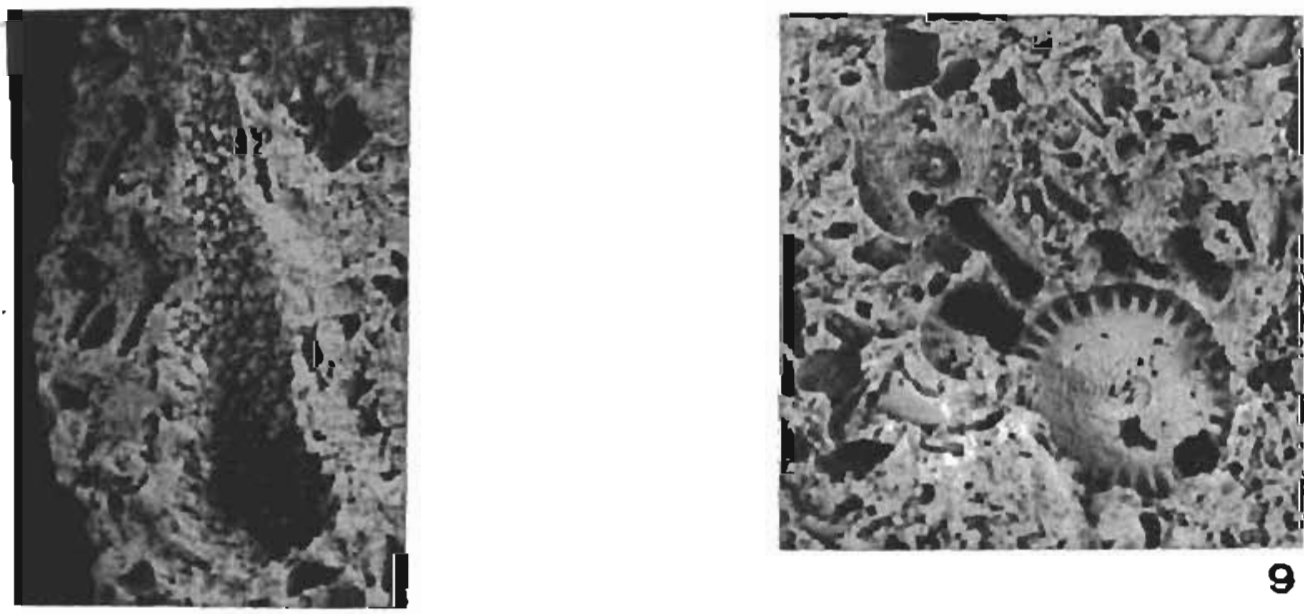

9

Figure 3. Megafossils recovered from locality 0IRB58, Mi. Hoyes A-5 Quadrangle, southcentral Alaska. I-2. Chonetinella sp., UAM 2651, ventral extemal mold, $\times 8$, latex replica positive of same exlernal mold, $\times 12$. Note typical strongly bilobed character of the shell and its finely capillate micro-ornamentation, bath of which are typical for the genus. 3-4, echinoconchid brachiopod, genus and species indeterminate, UAM 2652 , dorsal internal mold and counterpart latex positive, $\times 5.5$, indeterminate smoorh brachiopod, UAM $2653, \times 4.6$, Spiriferellina sp., UAM 2654, fragment of anterior portion of shell, $\times 8.7$, indeterminate ribbed brachiopod, UAM 2655, shell fragment, $\times 10.8$, stick-like, generically indeterminate cryptostome bryozoan fragment, UAM 2656, $\times 10$. 9. crinoid ossicles (stem fragments) of varying sizes and morphotypes, UAM 2657. $\times 7$. All illustrated specimens are deposited in the University of Alaska Museum (abbreviation UAM) at Fairbanks. Alaska. 
faunal character of the Late Triassic biota (as indicated by the abundance of calcareous green algae, abundant colonial corals, and sphinctozoan sponges). It is now commonly inferred that these terranes all had a major component of southerly motion in Triassic time, allowing them to be bathed in much warmer waters. An altemative. but less favored, interpretation would be that this climatic difference is a result of a more heightened global climatic gradient during Permian time.

\section{SILICEOUS ARGILLITES ("CHERTS") SAMPLED FOR RADIOLARLANS}

Several highly siliceous, almost cherty, argillite intervals were identified in the lower subunit of the Wildhorse Canyon section (ML Hayes A-5 Quadrangle) as probably being good targets for radiolarian analysis. Three samples were collected (0IRB57, 0IRB59A, and $01 \mathrm{RB} 65$ ) and were processed in dilute hydrofluoric acid for recovery of radiolarians. Unfortunately, none of the sample yielded any preserved specimens of radiolaria. Dr. Paula Noble, University of Nevada Reno, Reno, Nevads, who is a radiolarian expert, also confirmed this absence.

\section{LIMESTONES ANALYZED FOR CONODONTS}

Only two limestone horizons (01RB54, 01RB55) were identified on the east side of the creek bed forming the Wildhorse Canyon section in the Mt. Hayes A- 5 Quadrangle; both were situated within the argillites of the upper subunit. The lower horizon (0IRBS5) consists of a black, impure calcareous mudstone interval about $0.7 \mathrm{~m}$ thick and medium-bedded (individual beds up to $5-6 \mathrm{~cm}$ thick). The upper horizon (0IRB54) consists of a distinctive-weathering 0.3 -m-thick, dark gray lime mudstone concretion. Lange samples $(>7 \mathrm{~kg}$ ) were collected from both horizons and run in the laboratory for conodonts. Due to the highly impure nature of both carbonate samples, they were crushed to fine pebbleto-granule size and then dissolved in both formic and acetic acids. Large, voluminous residues were recovered from both samples, requiring several weeks to scan under a binocular microscope. Despite the unusually large size of sampled material analyzed (residues saved on a 230 -mesh sieve screen), both samples gave negative results. No other organic remains were observed in the residues (i.e., sponge spicules or radiolarians). The great abundarce of pyrite rhombs in the residues is accordant with the interpretation that both samples represent deposition in a relatively deep, anoxic paleoenvironment.

An additional limestone horizon (locality 0IRB51) was identified in the Mt. Hayes A-4 Quadrangle at or near the same spot where indeterminate fossil bryozo- ans were identified by Norm Silberling (in Nokleberg et al., 1992, fossil locality 125 [also noted earlier in Nokleberg ef al., 1982]). As noted above, although a diligent search for bryozoans was made by the author, it revealed only siliceous pseudofossils (or stringers), which one could possibly mistake for bryozoans. The limestone consists of light gray to white (brownish gray on fresh surface) recrystallized lime mudstone. Approximately 4-5 kg (9-1) lbs) of limestone from this locality was dissolved in acetic acid, but unfortunately no conodonts were noted in the residues. In addition, no other organic remains (i.e., sponge spicules, radiolarians) were noted in the fine residues.

\section{UPPER TRIASSIC SEDIMENTARY INTERBEDS OF THE NIKOLAI GREENSTONE}

A modest amount of time was also given to trying to locate additional data on the very limited fauna previously reported by N.J. Silberling in Nokleberg et al. (1992; locality 124 in their Tmp [Pillow basalt flows member of the Nikolai Greenstone]), although this was not the focus of the field study. This fauna consisted of some very poorly preserved material identified as belonging to either the flat clam Daonella or Halobia. Sedimentary interbeds of thin-bedded platy shale within the lower part of the Nikolai Greenstone at localities OIRB41 and 0IRB52 were examined, but yielded no identifiable megafauna In October 2001 the author had the opportunity to searcb for the above-mentioned flat clam collection in the USGS Triassic collections in Denver, Colorado, but this collection was not found in the several drawers of Triassic materials from the central Alaska Range. A more closely determined generic identity would be useful, in that Daonella and Halobia have effectively mutually exclusive ranges. Daonella is limited to the Middle Triassic, while Halobia is essentially known only from the lower part (Camian to middle Norian) of the Upper Triassic (Silberling, 1963, 1975; Silberling el al., 1997; McRoberts, 1997).

\section{ACKNOWLEDGMENTS}

The author acknowledges the vast wealth of information received from rwo geologists associated with ongoing mapping effors of M.A.N. Resources in the Amphitheater Mountains: (1) Lanry Hulbert of the Geological Survey of Canada; and (2) William Ellis, consultant from Anchorage. Theis experience with the regional geology was of tremendous help in selecting sites for a more detailed field study of pre-Nikolai Greenstone sediments in the Amphitheater Mountains area I am also grateful to Norman Silberling of Denver, Colorado, who was formerly the USGS Triassic expen, for sharing his vast knowledge of A laskan Triassic geology, 
as well as his field experience in the short time he spent in the Tangle Lakes region with Davey Jones (also retired from the USGS) during the early pioneer days of Alaskan terrane studies. The author also appreciates the contribution of Paula J. Noble, University of Nevada, Reno, Nevada, who helped in the examination for radiolarians from chens in the Wildhorse Canyon section. The flying skills of Warren Rogers, the helicopter pilot associated with the project, were also most helpful in getting into this remote field area. This report also benefited from the thoughtful reviews it received from Laurel E. Burns, A laska Division of Geological \& Geophysical Surveys, Fairbanks, and Arthur J. Boucot, Oregon Stace University, Corvallis, Oregon.

\section{REPERENCES}

Blodgett, R.B., and Clautice, K.H., 1998a, Paleontology of the Chulitna terrane and surrounding area, Healy A-6 quadrangle, south-central Alaska: Alaska Geology, Newsletter of the Alaska Geological Society, Inc., v. 27, no. 5, p. 6.

1998b, New insights into the stratigraphy and paleontology of the Chulima terrane and surrounding area, Healy A-6 quadrangle, souch-central Alaska, 2 p. (no pagination), in Karl, S.M., ed., The Alaska Geological Sociery 1998 Science and Technology Conference, 'Cutting Edge in Alaska.' 2000, Fossil locality map for the Healy A-6 Quadrangle, southcentral Alaska: Alaska Division of Geological \& Geophysical Surveys Report of Investigations 2000-5, 42 p., 1 pl.

Blodgett, R.B., and Frýda, J., 2001, Upper Triassic gastropod biogeography of western North America: Geological Society of America Abstracts with Programs, v. 33, no. 3, p. A-53.

Blodgetr, R.B., Fryda, J., and Stanley, GD., Jr., 200I, Delphinulopsidae, a new neritopsoidean gastropod family from the Upper Triassic (late Camian or early Norian) of the Wallowa terrane, northeastem Oregon: Journal of Czech Geological Society, v. $46(3 / 4)$, p. $221-232$.

Chao, Y.T., 1927, Productidze of China, Part I Producti: Palaeontogia Sinica, series B, v, 5, fascicule 2, 192 P., 16 pls.

Dunbar, C.O., 1955, Permian brachiopod faunas of central east Greenland: Meddelelser om Gronland, v. 110, no. 3, 169 p., 32 pls.

Dutro, J.T., Jr., 196!, Comelation of the Arctic Pemian, in Short papers in the geologic and hydrologic sciences: U.S. Geological Survey Professional Paper 424-C, p. C225-C228.

Dutro, J.T., Jr., and Saldukas, R.B., 1973, Permian paleogeography of the Arctic: Joumal of Research of the U.S. Geological Survey, v. 1, no. 5, p. 501507.
Frederiks, George, 1924 (imprint 1919), O verkhnekamennougol'nykh spiriferidakh Urala: Izvestiya Geologicheskii Komitet, v. 38 (1919), по. 2, p. 295-324.

Hillhouse, J.W., 1977, Paleomagnetism of the Triassic Nikolai Greenstone, McCarthy quadrangle, A laska. Canadian Joumal of Earth Science, v. 14, p. 25782592.

Kalashnikov, N.V., 1980, Brakhiopody verkhnego paleozoya evropeiskogo severa SSSR: "Nauka", Leningrad, 136 p., 39 pls.

Ludvigsen, Rolf, and Beard, Graham, 1997, West Coast Fossils: A Guide to the Ancient Life of Vancouver Island, Second Edition: Madeira Park, B.C., Harbour Publishing, $216 \mathrm{p}$.

McRoberts, C.A., 1997, North American halobiid bivalves: diversity trends and circum-Pacific correlation, p. 198-208, in Dickins, J.M., Yang Zunyi, Yin Hongfu, Lucas, S.G, and Acharyya, S.K., eds., Late Palaeozoic and Early Mesozoic Circum-Pacific Events and Their Global Correlation: Cambridge University Press, $245 \mathrm{p}$.

Muir-Wood, Helen, and Cooper, GA., 1960, Morphology, classificiation and life habits of the Productoidea (Brachiopoda): Geological Society of America Memoir 81, 447 p., 135 pls.

Nokleberg, W.J., Albert, N.R.D., Bond, GC., Herzon, P.L., Miyaoka, R.T., Nelson, W.H., Richter, D.H., Smith, T.E., Stout, J.H., Yeend, Warren, and Zehner, R.E., 1982, Geologic map of the southern part of the Mount Hayes quadrangle, Alaska: U.S. Geological Survey Open-File Report 82-52, 26 p., I sheet (scale $1: 250,000$ ).

Nokleberg, W.J., Albert, N.R.D., Herzon, P.L., Miyaoka, R.T., and Zehner, R.E., 1981, Recognition of two subterranes within the Wrangellia terrane, southem Mount Hayes quadrangle, Alaska, in Alberh N.R.D., and Hudson. Travis, eds., The United States Geological Survey in Alaska: Accomplishments during 1979: U.S. Geological Survey Circular 823-B, p. B64-B66.

Nokleberg, W.J., Aleinikofr, J.N., Dutro, J.T., Jr., Lamphere, M.A., Silberling, N.J., Silva, S.R., Smith, T.E., and Tumer, D.L.. 1992, Map, tables, and summary of fossil and isotopic age data, Mt. Hayes quadrangle, eastern Alaska Range, Alaska: U.S. Geological Survey Map MF-1996-D, 43 p. 1 sheet (scale 1:250,000).

Pitrat, C.W., 1965, Spiriferidina, p. H667-H728, in Moore, R.G, ed., Treatise on Invertebrate Paleontology, Part H, Brachiopoda: The Geological Society of America and The University of Kansas Press, New York.

Rachebouef, P.R., 2000, Chonetidina, p. 362-423, in Williams, Alywn, ef al., Treatise on Invertebrate 
Paleontology, Part H, Brachiopoda, Revised, Volume 2: Linguliformea, Craniiformea, and Rhynchonelliformea (part): The Geological Society of America, Inc., and University of Kansas, Boulder, Colorado and Lawrence, Kansas.

Ramsbottom, W.H.C., 1952, The fauna of the Cafn Coed marine band in the Coal Measures at Aberbaiden, near Tondu, Glamorgan: Bulletin of the Great Britain Geological Survey, Paleontology, v. 4, p. 8-32.

Richter, D.H., and Dutro, J.T., Jr., 1975, Revision of the type Mankomen Formation (Pennsylvanian and Permian), Eagle Creek area, eastem A laska Range, Alaska: U.S. Geological Survey Bulletin I395-B, p. B1-B25.

Richter, D.H., Sharp, W.N., Dutro, J.T., Js., and Hamilton, W.B., 1977, Geologic map of parts of the Mount Hayes A-1 and A-2 quadrangles, Alaska: U.S. Geological Survey Miscellaneous Investigations Series Map 1-1031, I sheet (scale 1:63,360).
Silberling, N.J., 1963, Field guide to halobiid and monotid pelecypods of the Alaskan Triassic. U.S. Geological Survey Open-File Reporh 10 p., 6 pls.

Silberling, N.J., 1975, Biogeographic significance of the Upper Triassic bivalve Monotis in Circum-Pacific accreted terranes, p. 63-70, in D.G. Howell, ed., Tectonostratigraphic Terranes of the Circum-Pacific Region. Circum-Pacific Council for Energy and Mineral Resources, Earth Science Series, 1.

Silberling, N.J., Grant-Mackie, J.A., and Nichols, K.M., 1997, The Late Triassic bivalve Monotis in accrefed terranes of Alaska: U.S. Geological Survey Bulletin $2151,21 \mathrm{p}$.

Stout, J.H., 196, Geology of the Eureka Creek area, eastcentral Alaska Range: Alaska Division of Geological \& Geophysical Surveys Geologic Report 46, 32 p., 1 sheet (scale 1:63,360). 


\begin{abstract}
APPENDIX
UTM COORDINATES FOR FIELD STATIONS FROM THE BROXSON GULCH PROJECT (AMPHITHEATER MOUNTAINS AREA)
\end{abstract}

July 6 - July 16,2001

The UTM coordinates below are in NAD27, UTM zone 6.

OIRB40 UTM 550460, 6998994

OIRBAI UTM 548842, 6998516

01RB42 UTM 548901, 6998421

01RBA3 UTM 548960, 6998423

OIRB44 UTM 549050, 6998432

OIRB45 UTM 558537, 7000034

01RB46 UTM 558571, 7000092

01RB47 UTM 558731, 7000186

0IRB48 UTM 558707, 7000117

01RB49 UTM 559869, 6998917

OIRBSO UTM 559841, 6998984

OIRBS1 UTM 559712,6999009

OIRBS2 UTM 542901,7009270

01RB53 UTM 543027, 7009441

OIRB54 UTM 543043, 7009456

OIRBSS UTM 543023, 7009492

0IRB56 UTM 543128, 7009944

01RBS7 UTM 543112, 7009910

01RB58 UTM 541080, 7010965

OIRB59 UTM 542999, 700959 I

01RB59A (same coordinates as 01RB59)

01RB60 UTM 542998, 7009617

01RB61 UTM 550479,6994330

0IRB62 UTM 550289, 6994951

01RB63 UTM 550294, 6995096

01RB64 UTM 550192,6995321

01RB65 UTM 543109, 7009894

\section{Quadrangle}

Mt. Hayes A-5 quadrangle Mt. Hayes A- 5 quadrangle Mt. Hayes A-5 quadrangle Mit. Hayes A-5 quadrangle Mit. Hayes A-5 quadrangle Mt. Hayes A-4 quadrangle Mt. Hayes $A-4$ quadrangle Mi. Hayes $A-4$ quadrangle Mit. Hayes A -4 quadrangle Mi. Hayes A-4 quadrangle Mt. Hayes A-4 quadrangle Mit. Hayes A-4 quadrangle Mit. Hayes A-5 quadrangle Mt. Hayes A-S quadrangle Mt. Hayes A-5 quadrangle Mi. Hayes A- 5 quadrangle Mt. Hayes A-5 quadrangle Mt. Hayes A-5 quadrangle Me Hayes A-5 quadrangle ML Hayes A-5 quadrangle Mt. Hayes A-5 quadraugle $M$. Hayes $A-5$ quadrangle On Mt. Hayes A-4/A-5 quadrangle boundary Mt. Hayes A- 5 quadrangle $M t$. Hayes A-S quadrangle Mt. Hayes A-5 quadrangle Mt. Hayes A-5 quadrangle 